\title{
Physicochemical characterization of flours and rheological and textural changes of masa and tortillas obtained from maize fertilized with nejayote and ovine manure
}

\author{
María C. Valderrama Bravo ${ }^{1,2 *}$ (D), María A. Cornejo Villegas ${ }^{3}$, María L. Zambrano Zaragoza ${ }^{(0)}$, \\ Martha E. Domínguez Hernández ${ }^{4}{ }^{(0}$, Rosalba Zepeda Bautista ${ }^{5}$, and Juan A. Oaxaca Luna ${ }^{2}$ (i) \\ ${ }^{1}$ Department of Engineering and Technology, Campus 4, Multidisciplinary Research Unity, Laboratory 16 ( Transformation and \\ Emerging Technologies in Foods) Km. 2.5 Highway, Cuautitlan-Teoloyucan San Sebastian Xhala, Cuautitlan Izcalli, State of Mexico, \\ Mexico, C.P. 54714 , \\ ${ }^{2}$ Department of Mathematics, Campus 4, Km. 2.5 Highway Cuautitlan-Teoloyucan San Sebastian Xhala, Cuautitlán Izcalli, \\ State of Mexico, Mexico, C.P. 54714, \\ ${ }^{3}$ Department of Engineering and Technology. Campus 4. Multidisciplinary Research Unity, Laboratory 16. Km. 2.5 Highway \\ Cuautitlan-Teoloyucan San Sebastian Xhala, Cuautitlan Izcalli, State of Mexico, Mexico, C.P. 54714, \\ ${ }^{4}$ Department of Agricultural Science, Campus 4, Km. 2.5 Highway Cuautitlan-Teoloyucan San Sebastian Xhala, Cuautitlán Izcalli, \\ State of Mexico, Mexico, C.P. 54714, \\ Faculty of Superiors Studies Cuautitlan, National Autonomous University of Mexico (UNAM); \\ ${ }^{5}$ National Politechnic Institute, SEPI-ESIME Zacatenco, Professional Unit “Adolfo López Mateos”, Col. Lindavista, \\ Mexico, D. F. C. P. 07738. \\ Received November 5, 2019; accepted February 24, 2020
}

\begin{abstract}
The agronomic management of maize (Zea mays L.) modifies the structure and composition of maize grain and its products like flour, masa, and tortillas. Results have shown that the protein content in flour obtained from maize grains treated with nejayote applied at $150 \mathrm{~m}^{3} \mathrm{ha}^{-1}\left(10.36 \mathrm{~g} \times 100 \mathrm{~g}^{-1}\right)$ and nejayote applied at $75 \mathrm{~m}^{3} \mathrm{ha}^{-1}$ with ovine manure applied at $25 \mathrm{t} \mathrm{ha}^{-1}$ $\left(10.17 \mathrm{~g} \times 100 \mathrm{~g}^{-1}\right)$ was higher than that determined in flour treated with chemical fertilizer $\left(10.05 \mathrm{~g} \times 100 \mathrm{~g}^{-1}\right)$. The flours obtained from maize fertilized without nejayote showed the highest viscosity values and the lowest values were for chemical fertilizer $(2816 \mathrm{mPa} \mathrm{s})$ and $75 \mathrm{~m}^{3} \mathrm{ha}^{-1}$ of nejayote with ovine manure applied at $25 \mathrm{t} \mathrm{ha}^{-1}$ (2498 $\mathrm{mPa}$ s). The highest elastic and viscous moduli were obtained for masa with the following fertilization regimes: $75 \mathrm{~m}^{3} \mathrm{ha}^{-1}$ of nejayote with $25 \mathrm{t} \mathrm{ha}^{-1}$ of ovine manure, and $150 \mathrm{~m}^{3} \mathrm{ha}^{-1}$ of nejayote with $25 \mathrm{tha}^{-1}$ of ovine manure and the lowest values of these parameters were obtained for $75 \mathrm{~m}^{3} \mathrm{ha}^{-1}$ of nejayote with $50 \mathrm{t} \mathrm{ha}^{-1}$ of ovine manure. The cohesiveness of masa was the lowest for maize fertilized with nejayote applied at 75 to $150 \mathrm{~m}^{3} \mathrm{ha}^{-1}$, and $50 \mathrm{tha}^{-1}$ of ovine manure. The highest concentration of $150 \mathrm{~m}^{3} \mathrm{ha}^{-1}$ for nejayote and the lowest level for ovine manure applied at $25 \mathrm{tha}^{-1}$ had a positive influence on the production of nixtamal and tortilla.
\end{abstract}

Keywords: ovine manure, nejayote, pasting profiles, rheological parameters, masa, tortilla

*Corresponding author e-mail: carmenvalde@yahoo.com.mx

\section{INTRODUCTION}

Maize (Zea mays L.) is the most widely produced and consumed cereal in Mexico, and it is the raw material used to manufacture masa and tortilla. However, the maize plant requires nutrients like nitrogen, phosphorus, and potassium to produce high yields of seeds and grains. These nutrients may enter the soil through chemical fertilizers or manure and crop residues (Salazar et al., 2009). Pollution and the high cost of chemical fertilizers are making it necessary to use novel alternatives to fertilization. For example, the application of liquid manure to maize increases its yield and improves the balance amount of nutrients that the plant consumes and generates (Schröder et al., 2015). Likewise, nejayote is a by-product of the nixtamalization process that contains approximately $2 \%$ solids (pericarp, proteins, starch, calcium, germ, and others) (Valderrama-Bravo et al., 2012). Nejayote damages the environment because the small-scale producer disposes of it in the form of wastewater into the local drainage network. However, nejayote is an organic nutrient that contains ferulic acid, phenolic, and antioxidant compounds as well as colloids (Niño-Medina et al., 2009). Therefore, innovative and environmentally

(C) 2020 Institute of Agrophysics, Polish Academy of Sciences 
friendly research has been performed to reduce the pollutant load of nejayote. Examples of these activities include treatment by bioreactors and the use of chitosan to reduce biochemical oxygen demand (BOD) (López-Pacheco et al., 2019; Suarez-Meraz et al., 2016). Also, nejayote solids may be used as a substrate for fermentation with edible fungi, which has a positive influence on the content of free phenolic compounds and dietary fibre as well as its antioxidant activity, with potential use as a high added value food ingredient (Acosta-Estrada et al., 2019). Thus, nejayote treated with fermentation or composted and mixed with manure could be used as an alternative organic fertilizer. Mahmood et al. (2017) applied it as an organic nutrient source with urea, and showed that the growth and yield of maize were substantially improved by fertilizer application alongside organic manures and that the soil total organic content increased when inorganic fertilizers were applied in combination with organic manures. Zepeda-Bautista et al. (2007) applied different doses of fertilizer to maize seeds $(\mathrm{N}, \mathrm{P}$, and $\mathrm{K}$ ); and reported that fertilization applied at $0.3 \mathrm{t} \mathrm{ha}^{-1}$ of nitrogen modifies maize structure, which consequently influences the nixtamalization process. On the other hand, Vázquez-Carrillo et al. (2015) mentioned that the physicochemical, rheological, and textural properties of masa as well as the quality of the tortillas depends on the maize type used and the conditions of the nixtamalization process. Valderrama-Bravo et al. (2017) reported that tortillas processed with hard maize (hybrid $\mathrm{H}-70$ ) had a more rigid texture. Conversely, tortillas from soft endosperm contained more swollen starch granules, which improves softness. Osorio-Díaz et al. (2011) attributed these results to a higher retrogradation rate. Santiago-Ramos et al. (2017) reported that hard maize starch showed the highest gelatinization temperature and the lowest enthalpy due to its highly compacted endosperm and high amylose content. Tortillas of intermediate and soft grains had a higher retrogradation rate than the tortillas of hard grains. Therefore, the objective of this research was to evaluate changes in flours, masa, and tortillas obtained from maize grains fertilized organically with nejayote and ovine manure. This research is based on the assumption that fertilization is decisive in the growth and development phase of the maize plant. Different regimes of nutrient application or fertilizer type produce changes in grain quality. Therefore, it is to be expected that these differences would show in the physical and chemical properties of the flours, masa, and tortillas obtained from such maize grains.

\section{MATERIALS AND METHODS}

Field experiments were conducted in "Laguna Seca" Ranch, Ahuazotepec, Puebla, during the spring-summer agricultural cycle of 2016. The maize hybrid AS-722 $\left(\right.$ Aspros $^{\mathrm{TM}}$ ) was sown at a density of 75000 plants per ha. Field experiments were conducted in the "Laguna Seca"
Ranch, Ahuazotepec, Puebla, during the spring-summer agricultural cycle of 2016. The maize hybrid AS-722 $\left(\right.$ Aspros $^{\mathrm{TM}}$ ) was sown at a density of 75000 plants per ha on April 25. The experimental plot was located at $20^{\circ} 01^{\prime}$ $51.6^{\prime \prime} \mathrm{N}$ and $98^{\circ} 07^{\prime} 15.6^{\prime \prime} \mathrm{W}$, at an altitude of $2268 \mathrm{~m}$ a.s.l. The soil is characterized as medium textured Andisol. The experiment design was carried out as a factorial with two factors and three levels: nejayote $\left(\mathrm{m}^{3} \mathrm{ha}^{-1}\right)$ : N0 $=0$, $\mathrm{N} 1=75$, and $\mathrm{N} 2=150 \mathrm{~m}$ and ovine manure $\left(\mathrm{t} \mathrm{ha}^{-1}\right): \mathrm{A} 0=0$, $\mathrm{A} 1=25$, and $\mathrm{A} 2=50$ ). An additional chemical fertilization treatment was established for comparison, where urea, ammonium diphosphate and potassium chloride $\left(\mathrm{CO}\left(\mathrm{NH}_{2}\right)_{2},\left(\mathrm{NH}_{4}\right)_{2} \mathrm{HPO}_{4}\right.$ and $\left.\mathrm{KCl}\right)$ were used as sources of N, P and K, respectively $\left(\right.$ Agrogen $^{\mathrm{TM}}$ ). Nejayote was obtained from the mills of the region and it was produced during a nixtamalization process, in which maize grains $(50 \mathrm{~kg})$ were cooked $(2 \mathrm{~h})$ and steeped $(16 \mathrm{~h})$ in alkaline conditions $0.36 \% \mathrm{Ca}(\mathrm{OH})_{2}$, Nixtacal $1 \mathrm{TM}$, Mexico) to make nixtamal, and then tortillas. On a daily basis the cooking liquid (nejayote) was collected in $30 \mathrm{~L}$ plastic containers. Nejayote characterization was performed by DominguezHernández et al. (2020). The experimental plots were set up as randomized blocks designed with three replicates per treatment. Each experimental unit consisted of six rows $10 \mathrm{~m}$ long and $0.8 \mathrm{~m}$ wide. The nejayote and ovine manure mixtures were composted in plastic containers for 20 days, stirring daily the first five days of nejayote collection time, and then stirring every other day the remaining time (15 days).

The organic and chemical fertilizers were applied manually at 20,40, and 60 days after sowing (Fig. 1). A physicochemical analysis $(\mathrm{pH}$, organic matter, nitrogen, phosphorus and potassium) of nejayote, manure and mixtures were presented in Dominguez-Hernández et al. (2020).

The harvest was carried out by hand when the formation of a black layer was observed, which indicated physiological maturity. The drying process was natural.

Maize grains were cleaned by removing foreign material, impurities, and broken grains. Twenty clean grains were measured (length, diameter, and thickness) and the geometric mean diameter $(\mathrm{Dg})$ was calculated according to Vilche et al. (2003) and Valderrama-Bravo et al. (2017). The hectolitre weight, flotation index and weight of 100 grains were evaluated according to Abdalaa et al. (2018). Moisture content was evaluated according to the AACC method 44-11 (AACC, 2000).

Samples were prepared by cooking $500 \mathrm{~g}$ of maize in a solution of $1500 \mathrm{~mL}$ of water and $5 \mathrm{~g}$ of food-grade calcium hydroxide (Fermont, Monterrey, Mexico). The maize samples were boiled at $90^{\circ} \mathrm{C}$ for $40-45 \mathrm{~min}$ and steeped for $12 \mathrm{~h}$. The nejayote was separated, and the nixtamalized samples were washed with $750 \mathrm{~mL}$ of water and milled in a manually operated mill (Nixtamatic, Edo. Mex., México). The nixtamal obtained was dried by using a forced air oven, at $55^{\circ} \mathrm{C}$ during $24 \mathrm{~h}$. The dried samples were milled using 


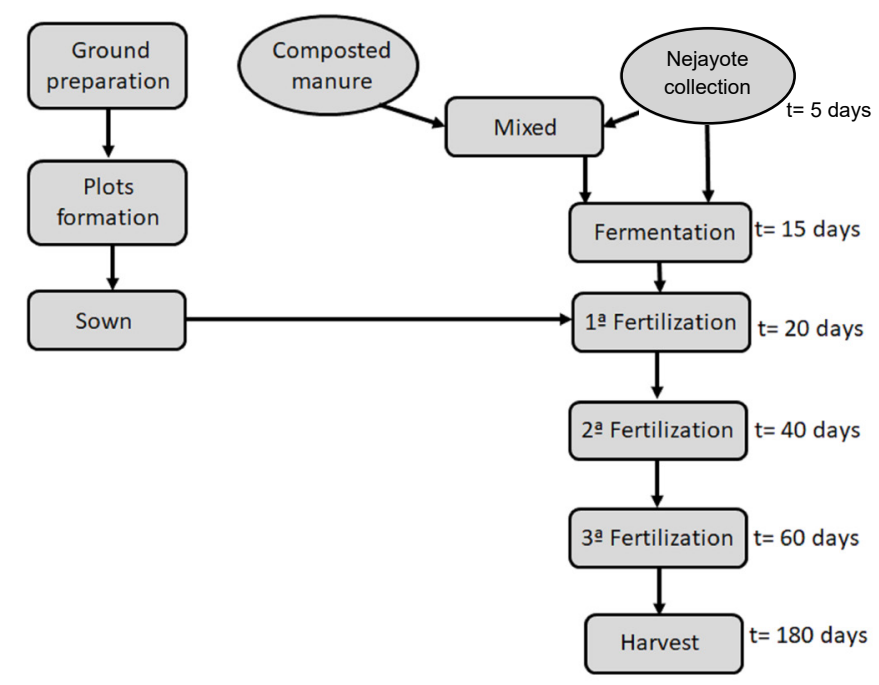

Fig. 1. Experimental diagram.

a hammer mill (Pulvex 200, Mexico) with a $0.8 \mathrm{~mm}$ mesh. The maize flours thus obtained were packed in airtight polyethylene bags and stored at $4^{\circ} \mathrm{C}$ until use.

Chemical analysis of maize flours, moisture content, ash, protein ( $\mathrm{N} x$ 5.85), fat and total fibre were evaluated according to AACC methods 44-15, 08-01, 46-13, 30-25 and 32-05, respectively (AACC, 2000).

The water solubility index (WSI) and swelling power (SP) were determined by applying the methodology described by Ayala-Rodríguez et al. (2009) and modified in the laboratory. Maize flour ( $1 \mathrm{~g}$, dry base) was weighed in a $15 \mathrm{~mL}$ centrifuging tube. Then $10 \mathrm{~mL}$ of distilled water was added. The flour suspensions were heated and shaken at $30^{\circ} \mathrm{C}$ for $30 \mathrm{~min}$ in a water bath. Then they were centrifuged at $3000 \mathrm{rpm}$ for $15 \mathrm{~min}$, the supernatant was decanted, and sediments were weighed to ascertain the swelling power. The supernatant was dried at $105^{\circ} \mathrm{C}$ for $24 \mathrm{~h}$. All measurements were conducted in triplicate. The WSI and SP were calculated by Eqs (1) and (2), as:

$$
\begin{gathered}
W S I=\frac{\text { weight of dried supernatent solids }}{\text { weight of sample }} 100, \\
S P=\frac{\text { weight of sediment paste }}{\text { weight of sample - weight of dried supernatent soilds }} .
\end{gathered}
$$

The starch pasting profiles of nine water suspension samples were analysed using an Anton Paar MCR 102 Rheometer, equipped with a starch cell using the methodology proposed by Rincon-Londoño et al. (2016). The starch samples $(3 \mathrm{~g})$ were suspended in $18 \mathrm{~mL}$ of water. The suspension was heated over $5 \min$ from 50 to $90^{\circ} \mathrm{C}$; next, the suspension was maintained at a constant temperature of $90^{\circ} \mathrm{C}$ for $5 \mathrm{~min}$ and finally the samples were cooled down to $50^{\circ} \mathrm{C}$ for $5 \mathrm{~min}$. The rotation speed of the system was $194 \mathrm{rpm}$.
Maize flours were rehydrated until they reached 54\% of moisture to obtain rollable masa. The colour of the masa samples were measured using a Minolta CR-300 colorimeter (Minolta, Osaka, Japan). The colour parameters $\operatorname{CIELAB}\left(L^{*}, a\right.$, and $b$, where $L^{*}=$ luminosity $(100=$ white, to $0=$ black), the a $=$ greenish-reddish, and $b^{*}=$ yellowishbluish. The total colour difference was also calculated $(\Delta E)$ by Eq. (3). The $L^{*}=98.75, a=0.72$ and $b=2.58$ values were evaluated with a white reference:

$$
\begin{array}{r}
\Delta E=\sqrt{(\Delta a)^{2}+(\Delta b)^{2}+(\Delta L *)^{2}}, \\
\Delta a=a_{\text {masa }}-a_{\text {reference }}, \Delta b=b_{\text {masa }}-b_{\text {reference }}, \\
\Delta L *=*_{\text {masa }}-L *_{\text {reference. }}
\end{array}
$$

The rheological tests of the masa were performed with the use of an Anton Paar MCR-102 rheometer equipped with a $2.5 \mathrm{~mm}$ rough plate. A dynamic deformation percentage sweep test was conducted to determine the linear viscoelastic region (LVR) in a range of 0.1 to $1 \%$ at $25^{\circ} \mathrm{C}$. Frequency sweeps, which increased from 0.1 to $10 \mathrm{~Hz}$, were evaluated to determine the storage (elastic) modulus $\left(\mathrm{G}^{\prime}\right)$ and loss (or viscous) modulus $\left(\mathrm{G}^{\prime \prime}\right)$ using the accompanying software.

Masa and tortilla analysis were performed using a Texture Analyser Brookfield Model CT3 25 K USA. Cylindrical masa (35 g) was formed with a stainless-steel mould (45 $\mathrm{mm}$ diameter and $15 \mathrm{~mm}$ high). Samples were kept in a polyethylene bag for $15 \mathrm{~min}$, and then the texture profile analysis (TPA) of the masa was performed. The samples were measured to a $33 \%$ compression cycle using a TA General Probe Kit with a TA25/1000 test probe cylinder $50.8 \mathrm{~mm}$ diameter and $20 \mathrm{~mm}$ length at a speed of $1 \mathrm{~mm} \mathrm{~s}^{-1}$. Two compression cycles were measured. Hence, it was possible to measure hardness, cohesiveness, adhesiveness, and elasticity. Three replications were conducted at $24 \pm 1^{\circ} \mathrm{C}$. 
The masa was shaped into discs (diameter, $10.9 \mathrm{~cm}$; thickness, $1.3 \mathrm{~mm}$; and weight, $30 \mathrm{~g}$ ) using a manual tortilla machine. The disc samples were laid on a "comal" frying pan and cooked at $\left(270^{\circ} \mathrm{C}\right)$ for $20 \mathrm{~s}$ on one side, and then turned over and baked for another $30 \mathrm{~s}$, finally, they were turned over again until they were inflated and bubbles were formed.

The tensile strength of the tortillas was measured using samples of $34 \times 70 \mathrm{~mm}$ (width $\times$ length). The samples were placed in retention pincers TA-DGA dual grip, and the test was carried out at a velocity of $2 \mathrm{~mm} \mathrm{~s}^{-1}$ until the tortilla was fragmented. The tensile strength was expressed as the peak force $(\mathrm{N})$ required to break the tortilla. Also, the extensibility was measured as the length of the masa until the breaking/cutting point. The tortilla rollability test was carried out by rolling the tortillas around an aluminium cylinder with a $2.5 \mathrm{~cm}$ diameter and $17.9 \mathrm{~cm}$ length at $1 \mathrm{~mm} \mathrm{~s}^{-1}$ of velocity. The force required to roll the tortilla was reported in $(\mathrm{N})$.

The Minitab ${ }^{\circledR}$ Statistical software, version 15 (Minitab Inc., State College PA, USA) was used to analyse data by applying ANOVA at a probability $\mathrm{p} \leq 0.05$, and significant differences among the means were defined by using the Tukey test. All of the measurements were conducted three times.

\section{RESULTS AND DISCUSSION}

The results of the physical characterization of the grains such as hectolitre weight and moisture showed no significant difference. The Mexican Official Standard NMX-FF-024/1-SCFI-2002 (SAGARPA, 2002), establishes a maximum moisture content of $14 \%$ for the conservation and storage of grains and a minimum hectolitre weight of $74 \mathrm{~kg} \mathrm{hl}^{-1}$. The moisture values obtained were $<14 \%$, and the hectolitre weight was $>74 \mathrm{~kg} \mathrm{hl}^{-1}$, both measures are within limits established in the Mexican Official Standard. Maize treated with organic fertilizer increased the weight of the 1000 grains; however, the weight of the 1000 grains for corn treated with chemical fertilizer and without fertilizer showed the lowest values (Table 1). The flotation index showed a significant difference because according to NMX-FF-024/1-SCFI-2002 (SAGARPA, 2002) the grains are classified as hard and very hard.

Chemicals analysis of the flours obtained from the maize treated with organic fertilizer showed a significant difference $(p \leq 0.05)$ between all treatments of the organically fertilized flours for protein, fat, ashes and fibre (Fig. 2). The determinations of the moisture values for the flours ranged

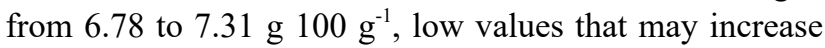
their shelf life during storage. The protein content of the flour obtained from maize grains N2-A0 (without manure

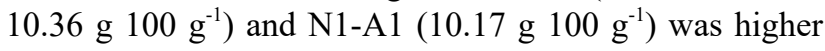
than that of the flour from treatment with chemical fertilizer

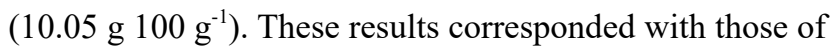
Flores-Farias et al. (2000), who reported protein contents of

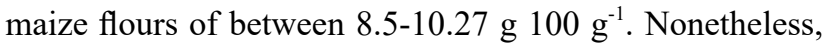
the protein contents obtained in our research were higher than the ones obtained by Bello-Pérez et al. (2014) for tra-

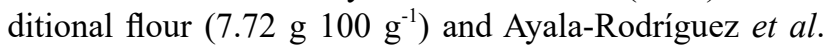

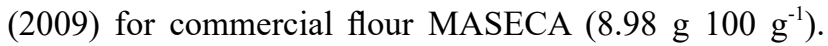
Nevertheless, all tortillas were found to contain high levels

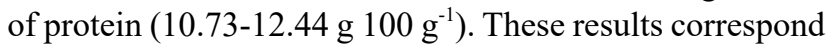
with the findings of Vázquez-Carrillo et al. (2012), who determined the protein content in tortillas processed from

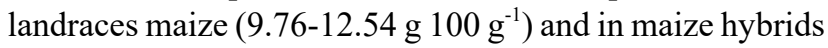

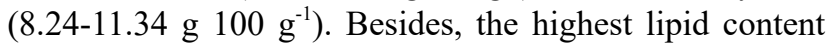
was found for N2-A1 (3.25 g $\left.100 \mathrm{~g} \mathrm{~g}^{-1}\right)$, a similar result to the ohmic heated flours produced by the batch process (Ramírez-Jiménez et al., 2019). Some authors have attributed this phenomenon to a saponification reaction caused

Table 1. Physical characterization of maize grains

\begin{tabular}{|c|c|c|c|c|c|}
\hline Maize & $\begin{array}{l}\text { Hectolitre weight } \\
\quad\left(\mathrm{kg} \mathrm{hL}^{-1}\right)\end{array}$ & $\begin{array}{l}\text { Moisture } \\
(\%)\end{array}$ & $\begin{array}{l}\text { Weight of } 1000 \\
\text { grains } \\
\text { (g) }\end{array}$ & $\begin{array}{c}\text { Flotation index } \\
(\%)\end{array}$ & Hardness \\
\hline N0-A0 & $76.67^{\mathrm{a}} \pm 2.52$ & $11.53^{\mathrm{a}} \pm 0.57$ & $333.23^{\mathrm{ab}} \pm 4.36$ & $15.5^{\mathrm{a}} \pm 1.0$ & Hard \\
\hline N0-A1 & $78.17^{\mathrm{a}} \pm 1.26$ & $13.20^{\mathrm{a}} \pm 0.26$ & $378.66^{\mathrm{a}} \pm 8.39$ & $13.5^{\mathrm{ab}} \pm 2.5$ & Hard \\
\hline N0-A2 & $77.83^{\mathrm{a}} \pm 0.29$ & $12.50^{\mathrm{a}} \pm 0.44$ & $371.67^{\mathrm{ab}} \pm 7.23$ & $14.0^{\mathrm{ab}} \pm 1.0$ & Hard \\
\hline N1-A0 & $77.67^{\mathrm{a}} \pm 0.58$ & $12.20^{\mathrm{a}} \pm 1.31$ & $365.30^{\mathrm{ab}} \pm 8.19$ & $10.0^{\mathrm{ab}} \pm 1.0$ & Very hard \\
\hline N1-A1 & $77.67^{\mathrm{a}} \pm 0.58$ & $11.90^{\mathrm{a}} \pm 0.20$ & $359.35^{\mathrm{ab}} \pm 9.17$ & $9.5^{\mathrm{ab}} \pm 0.5$ & Very hard \\
\hline N1-A2 & $77.83^{\mathrm{a}} \pm 0.76$ & $13.43^{\mathrm{a}} \pm 0.78$ & $374.33^{\mathrm{a}} \pm 7.77$ & $11.5^{\mathrm{ab}} \pm 1.5$ & Very hard \\
\hline $\mathrm{N} 2-\mathrm{A} 0$ & $77.33^{\mathrm{a}} \pm 1.26$ & $13.23^{\mathrm{a}} \pm 0.31$ & $372.33^{\mathrm{ab}} \pm 3.06$ & $7.0^{\mathrm{b}} \pm 1.0$ & Very hard \\
\hline N2-A1 & $77.50^{\mathrm{a}} \pm 0.50$ & $12.17^{\mathrm{a}} \pm 0.50$ & $361.67^{\mathrm{ab}} \pm 9.50$ & $12.0^{\mathrm{ab}} \pm 1.0$ & Hard \\
\hline $\mathrm{N} 2-\mathrm{A} 2$ & $77.33^{\mathrm{a}} \pm 0.2$ & $12.80^{\mathrm{a}} \pm 0.87$ & $368.25^{\mathrm{ab}} \pm 8.72$ & $14.0^{\mathrm{ab}} \pm 2.5$ & Hard \\
\hline $\mathrm{ChF}$ & $77.50^{\mathrm{a}} \pm 0.50$ & $12.47^{\mathrm{a}} \pm 2.04$ & $352.67^{\mathrm{bc}} \pm 3.46$ & $11.5^{\mathrm{ab}} \pm 1.5$ & Very hard \\
\hline
\end{tabular}

Mean \pm standard deviation values followed by a different letter in each row, are significantly different $(\mathrm{p}<0.05)$. 

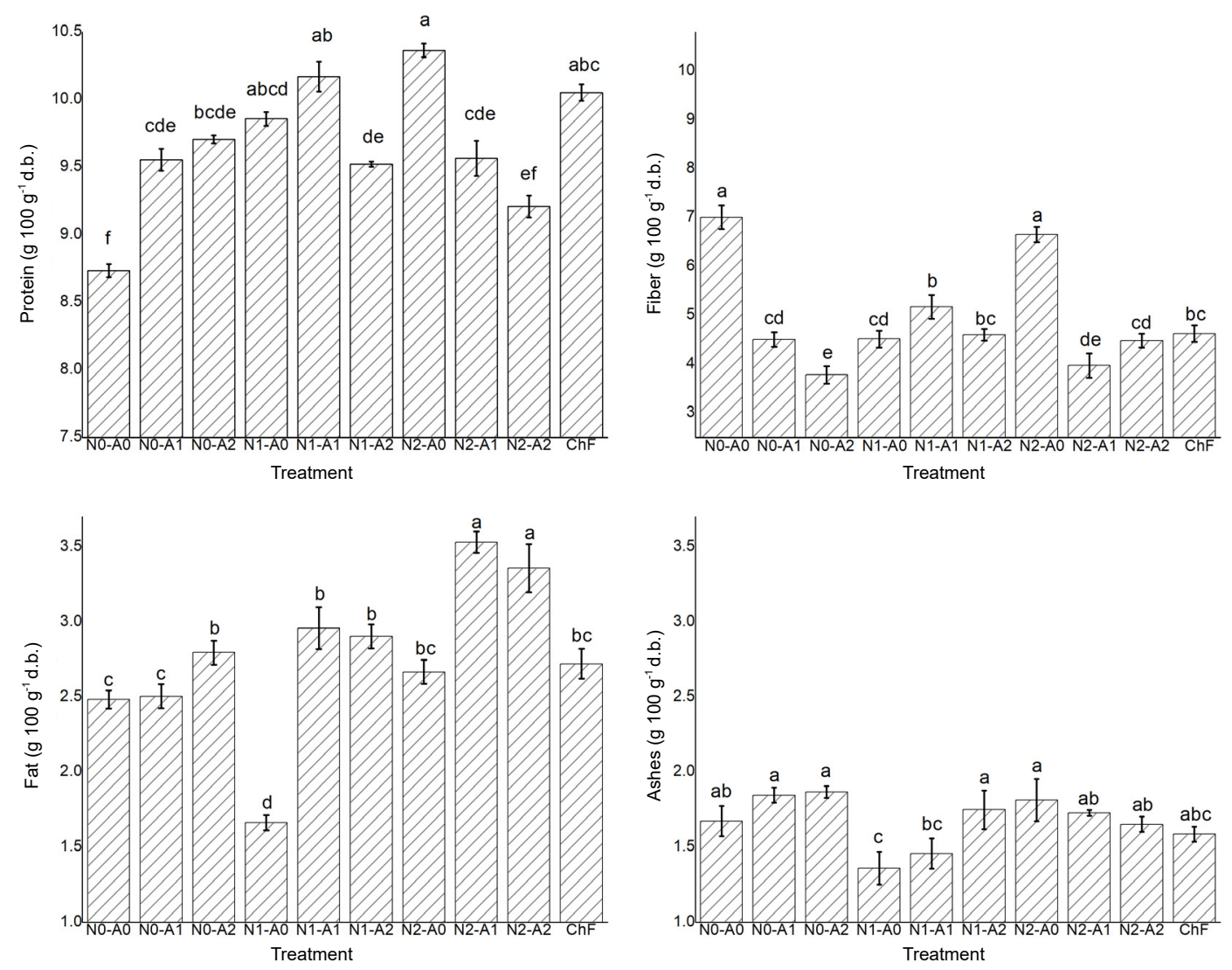

Fig. 2. Chemical analysis of different flours obtained from organically fertilized maize.

by the addition of $\mathrm{Ca}(\mathrm{OH})_{2}$ (Martinez-Flores et al., 2006). Moreover, the formation of amylose-lipid complexes has been reported during the alkaline cooking of corn (Thachil et al., 2014), which in turn, may be affected by the extraction and the quantification of lipids. Also, the fibre content of N0-A0 and N2-A0 was significantly greater than that of N0-A2. Maize flour N2-A0 presented a high protein content, and fibre; both are components that contribute to the formation of the food matrix (Camelo-Méndez et al., 2017). Maize flour N2-A0 was obtained from grains that were fertilized with fermented nejayote, which is a liquid that is rich in fibre and gums. Furthermore, it has been reported that fibre content contributes to water holding capacity, to the development of viscosity, and to the formation and gelling of the food matrices, and it has a specific affinity for ions and aromatics compounds (Vitaglione et al., 2008).

Flours obtained from maize grains treated with organic fertilizer presented a significant difference $(p \leq 0.05)$ in swelling power (SP) and water solubility index (WSI) (Fig. 3). The SP values are between 3.15-3.59 g $100 \mathrm{~g}^{-1}$, these results are similar to those reported for nixtamalized maize flours (Ayala-Rodriguez et al., 2009; Flores-Farias et al., 2000). Maize flour N1-A2 was found to have a high-

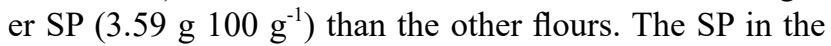
nixtamalized maize flours depends on protein content, $\mathrm{pH}$, enzyme-susceptible starch, and particle size and the SP is
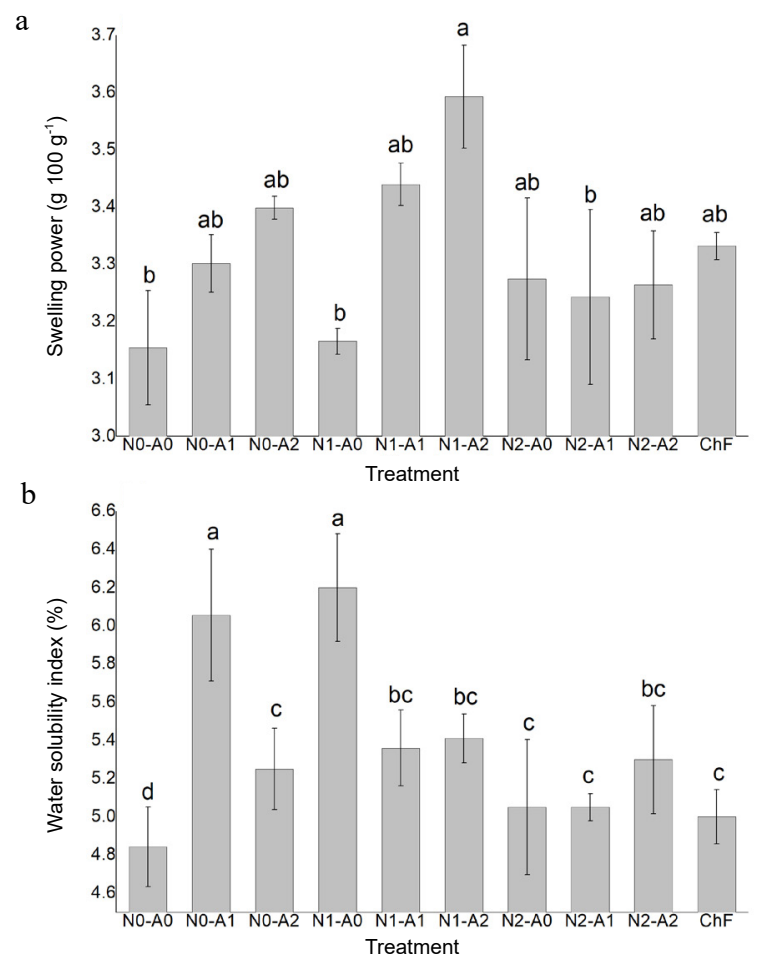

Fig. 3. Flours obtained from organically fertilized maize: a) swelling power and b) water solubility index. 
related to the presence of natural gums from the hydrolysis of the pericarp or additives (Flores-Farías et al., 2000). Furthermore, the hydration properties are associated with the structure of the porous matrix, formed by polysaccharide chains that may contain large amounts of water due to the formation of hydrogen bonds (Kethireddipalli et $a l ., 2002)$. Additionally, the protein within the maize flour can also hold water through weak forces such as hydrogen bonds (Shi et al., 2016). On the other hand, Jan et al. (2017) suggested that the high SP may be linked to a low amylose content, reinforcing the internal network within the starch granules, thereby restricting the swelling power. Water solubility index values (WSI) had a range of 4.84 to $6.20 \%$. These numbers are higher than the ones previously reported by Shi et al. (2016) and Ayala-Rodríguez et al., (2009). However, these values are, according to other research, 4.4 to $7.2 \%$ (Flores-Farías et al., 2000). The water solubility index was determined as an approximate measure of the soluble starch and the soluble proteins in the flour samples (Wang et al., 2010). This fact may indicate the degree of maize cooking. However, the WSI provides evidence of the interaction magnitude between the starch chains within the amorphous and the crystalline domains. The solubility of the different flours differs due to the different treatments of organic fertilization in the maize grains. Likewise, the increase in water solubility could refer to a partial disruption of the amylopectin helices and a greater ability of the
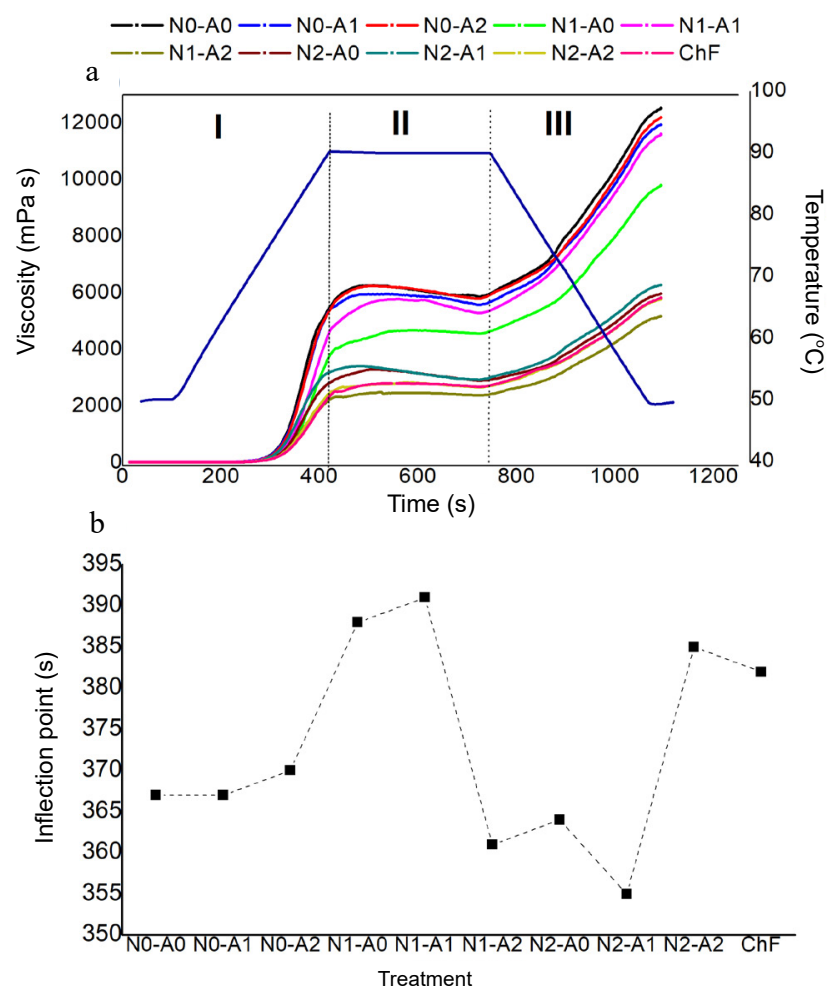

Fig. 4. Apparent viscosity of flours from fertilized maize: a) pasting profile $b$ ) inflection points. amylose to leach out from the damaged granules during the nixtamalization process (Rocha-Villareal et al., 2018; Mir et al., 2013).

The pasting profile (Fig. 4a) was divided into three stages as follows: stage I is the heating process of the starch slurry from $50-90^{\circ} \mathrm{C}$; stage II is the isothermal process at $90^{\circ} \mathrm{C}$; finally, stage III is the cooling process from $90-50^{\circ} \mathrm{C}$. In all phases, changes in viscosity to the maize flours were observed. For stage I, the inflection point (Fig. 4b) shows the time in which drastic changes occur before reaching a state of maximum viscosity in the flour slurry. This point may be related to the time taken for the starch granule to become fully swollen without changing its granular form. Likewise, Rincón-Londoño et al. (2016) reported drastic changes in starch morphology from granules to "donuts" at the maximum peak of the pasting profile which occurs at the maximum viscosity of the flour slurry. The graphs show similar inflection points (367-370 s) and a maximum gelatinization temperature of the slurry at $87^{\circ} \mathrm{C}$ obtained for fertilized maize without nejayote (N0-A0, N0-A1, and N0-A2). Meanwhile, the flour slurry N1-A1 showed the highest inflection point (391 s) at a temperature of $89.6^{\circ} \mathrm{C}$. During this stage, the starch granules of these flours absorb water more slowly and swell when heated continuously.

In stage II, the maximum viscosity peak was reached. The fertilized maize without nejayote N0-A0, N0-A1 and N0-A2 (6272, 5961, and $6255 \mathrm{mPa}$ ) showed the highest viscosity values respectively. The lowest viscosity values are correlated with the maize produced with chemical fertilizer (2816 mPa s) and N1-A2 (2498 mPa s). Villada et al. (2017) hypothesized that the viscosity peak was related to hydrogel formation (corn-lime-water) and that starch is the main reason for the increase in viscosity. Through cooling, the viscosity level reached at the end of stage III for flour N0-A0 was 2.5 times higher $(12550 \mathrm{mPa} \mathrm{s})$ than that of $\mathrm{N} 1-\mathrm{A} 2$ (5 $179 \mathrm{mPa} \mathrm{s}$ ).

Starch is an important store of energy that is captured by plants using sunlight, water, carbon dioxide, and soil nutrients (Keeling and Myers, 2010). In this research, the flours were obtained from maize grains which were organically fertilized with nejayote, manure and mixtures of the two, 20,40, and 60 days after sowing; during this period of plant growth possible modifications in the starch structure may occur. Starch is known as a semicrystalline material because the granules contain crystalline and amorphous regions. These crystalline regions are mainly amylopectin polymers from which the outer branches are hydrogen bonded to each other. The amorphous regions of the granules are mainly composed of amylose and amylopectin branch points (Athene, 2001). On the other hand, nejayote is constituted by $\mathrm{CaCO}_{3}$, fibre, proteins, fat, ash (Valderrama-Bravo et al., 2013) and $\mathrm{OH}$ ions which are a product of alkalizing reactions during the nixtamalization process with $\mathrm{pH} 11$. However, during composting, the levels of $\mathrm{pH}$ vary in response to the raw material used in 
the original composting mixture. In the first days of active composting, the period is characterized by a drop in the $\mathrm{pH}$ value to levels between 4 and 5; this may be the result of the formation of organic acids (USDA, 2010).

Therefore, the changes in composted nejayote could modify the crystalline and amorphous regions of the starch forming a new hydrogen bond between amylose and amylopectin. Consequently, changes in pasting properties occur in all flours. They occur because changes in starch content take place during gelatinization and this has been attributed to the differences between the amorphous and crystalline regions (Wajira and David, 2006). Also, viscosity changes may be associated with the high ash content of the flours N0-A0, N0-A1, and N0-A2 (Fig. 2). Santiago-Ramos et al. (2015) indicated that the additional ash might induce crosslinks or ionic interactions among the maize flour components, mainly with proteins, which increases viscosity.

The total colour difference $(\Delta E)$ and " $b$ " parameters of maize masa showed significant differences $(p<0.05)$ among the masa samples. Masa N1-A0 showed the highest $\Delta E$ (32.47) and the lowest " $b$ " value (10.88). Conversely, the masa N0-A1 (14.42) and N2-A2 (13.43) showed the highest " $b$ " values, which indicated that the masa had a stronger shade of yellow. Ayala-Rodriguez et al. (2009) reported that lime quantity affects the colour of the nixtamalized maize flours and Amador-Rodríguez et al. (2019) revealed that the yellow colour in masa depends on calcium hydroxide concentration and on the pericarp percentage retained by the grain during the nixtamalization process. However, if maize grains were nixtamalized under equal process conditions in all experiments; then physical properties like hardness, colour, and the size of maize grains in masa and tortillas would be modified by genotypic variation and environmental growth conditions (Vázquez-Carrillo et al., 2012). Likewise, Zhang et al. (2015) indicated that ovine manure application in soils are beneficial to the buffering of soil acidification to avoid harmful effects on plant growth, which changes the chemical and physical properties of maize grains. Hence, mixtures composted with ovine manure and nejayote buffered the $\mathrm{pH}$ value because organic solids from ovine manure probably contain a high quantity of microorganisms like fungi, which consume the acids produced during the first stages of composting. Consequently, the masa N2-A1 obtained from organically fertilized maize grains and with chemical fertilizer, produced a yellow colour and low $\Delta E$ value.

The results of rheological parameters were within the region of linear viscoelasticity (where the moduli are independent of the strain); they showed a constant strain range between 50 and $80 \mathrm{~Pa}$. As a consequence, a strain of $70 \mathrm{kPa}$ was chosen to carry out all oscillatory frequency tests. The results of the sweep frequency for elastic moduli $\left(G^{\prime}\right)$ and viscous moduli $\left(G^{\prime \prime}\right)$ that were dependent on frequency showed significant differences $(p<0.05)$ between all of the treatments. In all masa samples, $G^{\prime}$ values pre- dominated over $\mathrm{G}^{\prime \prime}$ values (Fig. 5). This fact indicates that the behaviour of masa is similar to that of a weak gel (Valderrama-Bravo et al., 2015). Valderrama-Bravo et al. (2017) and Vázquez-Carrillo et al. (2015) reported a similar behaviour. The highest elastic and viscous moduli values were produced by masa from N1-A1, and N2-A1 while the lowest $G^{\prime}$ and $G^{\prime \prime}$ values were produced by masa from N2-A2. The results show that the application of organic fertilizer to maize during its production modifies the viscoelastic modulus $\mathrm{G}^{\prime}$, and $\mathrm{G}^{\prime \prime}$ of the produced masa. On the other hand, the mixtures of organic fertilizer N1-A1 $\left(75 \mathrm{~m}^{3}-25 \mathrm{tha}^{-1}\right)$ and N2-A1 $\left(150 \mathrm{~m}^{3}-25 \mathrm{tha}^{-1}\right)$ used for the fertilization of maize during its production generated a higher content of phosphorus, potassium, and sodium (Domínguez-Hernández et al., 2020).

Higher plants, like maize, synthesize and store starch in the form of granules in storage tissues such as seeds, and in a temporary form in leaves, roots, and stems (Keeling and Myers, 2010; Song et al., 2016). Little starch is accumulated during the 'cell division' or endosperm differentiation phase ( 10 DPA), which defines the final cell number of the grain (Altenbach et al., 2003). Fertilization, supplied mainly by nitrogen $(\mathrm{N})$ changes the composition of maize grain, by modifying the starch, protein, and oil content

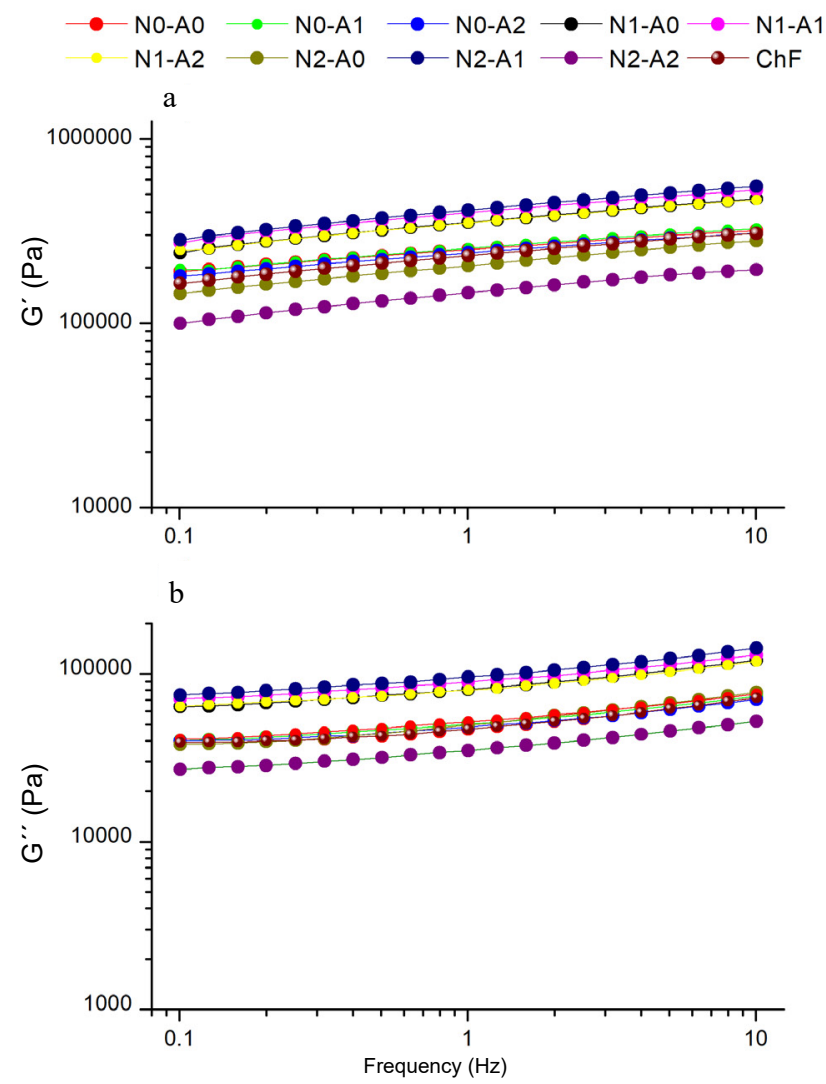

Fig. 5. Rheological parameters of masa obtained from organically fertilized maize a) elastic module $\left(\mathrm{G}^{\prime}\right)$ and b) viscous module $\left(\mathrm{G}^{\prime \prime}\right)$. 
(Tofiño et al., 2007; Seebauer et al., 2010). Also, nitrogen deficiency before or during the early reproductive development stages decreased the accumulation of starch in the kernel (Thitisaksakul et al., 2012). The $\mathrm{N}$ supply from the organic fertilizers (nejayote-manure) was commenced 20 days before anthesis could change the composition of the maize kernel by modifying the starch structure. The use of the organic fertilizer meant that N2-A2 had the highest content of nitrogen in the grain (Domínguez-Hernández et al., 2020) and the masa obtained from the fertilized maize with this mixture showed drastic changes in $\mathrm{G}^{\prime}$, and $\mathrm{G}^{\prime \prime}$ (Fig. 5).

Likewise, Contreras-Jiménez et al. (2017) noted that the main components of nixtamalized flours that might affect the viscoelastic properties of masa are starch, non-starch polysaccharides, proteins, lipids, and minerals. In addition, nejayote contains hemicellulose, cellulose, arabinoxylans (non-cellulosic cell wall polysaccharides present in maize pericarp) and phenolic acids like ferulic acid (Niño-Medina et al., 2009; Daglia, 2012). During the composting process of nejayote with manure by microorganisms, the biodegradation of hemicellulose, cellulose and another polymers to short lateral chains like sugars occurs (Pérez et al., 2002). Similarly, Pei-Yin and His-Mei (2011) stated that the conversion of free sugars to starch resulted in the progressively-decreasing total sugar content of the developing grains. Also, the mixtures of organic fertilizer with nejayote have a higher content of sugars that are nutrients for the maize plant, which could modify the starch structure. Consequently, the viscoelastic moduli $G^{\prime}$ and $G^{\prime \prime}$ of the masa obtained from the organically fertilized maize were different.

The parameters of texture profile analysis, obtained for the prepared masa according to the experimental design (Table 2) show that the masa from fertilized maize with nejayote at $75 \mathrm{~m}^{3} \mathrm{ha}^{-1}$ contributed to an increase in the hardness of the masa by $50 \%$ with respect to those without nejayote and ovine manure (N0-A0). This effect was great- er in the masa from maize that was fertilized with greater amounts of ovine manure (A2) during plant development. Hardness is a parameter measured by the force required to deform the masa, at optimal moisture conditions, without causing its disintegration (Gaytán-Martínez et al., 2011). In addition, the masa fertilized with more ovine manure had a lower elasticity, which means that they adhere less to the surface when tortillas are prepared, this coincides with those results mentioned by Flores-Farías et al., 2000, who made a comparative study of nixtamalized maize flours and commented that adhesiveness is associated with sticky masa and low machinability. The cohesiveness of the masa from maize fertilized with 75 or $150 \mathrm{~m}^{3} \mathrm{ha}^{-1}$ of nejayote and $50 \mathrm{t} \mathrm{ha}^{-1}$ of ovine manure was at its lowest level, which implies that the constituents of the masa had a lower mutual affinity. Therefore, the masa disintegrates more easily, suggesting that a more significant amount of ovine manure during the growth and development of the maize cob considerably reduces the cohesiveness properties of the masa prepared with this treated maize. Although it has been observed that the addition of nejayote does not show a significant effect on the textural parameters, it is necessary to control the amount of manure used as fertilizer, since the concentration influences the characteristics of the masa obtained. Cohesion is the force between the internal interactive bonds, the shape of the material structures (also known as "body") during compression and it is also an essential parameter in the preparation of tortillas. Therefore, the texture of the dough is crucial during tortillas production (Chel-Guerrero et al., 2014). Therefore it is necessary to control the addition of manure as fertilizer, and its concentration because it influences the characteristics of the masa obtained.

When considering the results obtained for the textural parameters of tortillas (Table 3), a lower resistance to stress is observed in the samples from maize produced with $150 \mathrm{~m}^{3} \mathrm{ha}^{-1}$ of nejayote (N2) and a more considerable

Table 2. Texture parameters of masa

\begin{tabular}{lcccc}
\hline Treatment & $\begin{array}{c}\text { Hardness } \\
(\mathrm{N})\end{array}$ & $\begin{array}{c}\text { Elasticity } \\
(\mathrm{mm})\end{array}$ & $\begin{array}{c}\text { Adhesiveness } \\
(\mathrm{mJ})\end{array}$ & Cohesiveness \\
\hline N0-A0 & $11.60 \pm 1.70^{\mathrm{ab}}$ & $3.29 \pm 0.68^{\mathrm{a}}$ & $6.63 \pm 1.05^{\mathrm{a}}$ & $0.3957 \pm 0.06^{\mathrm{a}}$ \\
$\mathrm{N} 0-\mathrm{A} 1$ & $10.51 \pm 0.46^{\mathrm{b}}$ & $1.91 \pm 0.21^{\mathrm{ab}}$ & $3.90 \pm 1.04^{\mathrm{abc}}$ & $0.4110 \pm 0.02^{\mathrm{a}}$ \\
N0-A2 & $10.12 \pm 0.30^{\mathrm{b}}$ & $2.38 \pm 0.26^{\mathrm{ab}}$ & $5.27 \pm 0.71^{\mathrm{abc}}$ & $0.3628 \pm 0.01^{\mathrm{a}}$ \\
N1-A0 & $14.05 \pm 2.08^{\mathrm{a}}$ & $1.93 \pm 0.40^{\mathrm{ab}}$ & $2.43 \pm 1.02^{\mathrm{bc}}$ & $0.3321 \pm 0.04^{\mathrm{ab}}$ \\
N1-A1 & $11.23 \pm 0.40^{\mathrm{ab}}$ & $1.88 \pm 0.06^{\mathrm{ab}}$ & $3.50 \pm 0.26^{\mathrm{abc}}$ & $0.3082^{\mathrm{ab}} \pm 0.02^{\mathrm{ab}}$ \\
N1-A2 & $14.01 \pm 0.32^{\mathrm{a}}$ & $0.86 \pm 0.06^{\mathrm{b}}$ & $3.30 \pm 1.02^{\mathrm{abc}}$ & $0.1486 \pm 0.03^{\mathrm{c}}$ \\
N2-A0 & $12.49 \pm 1.34^{\mathrm{ab}}$ & $2.14 \pm 0.29^{\mathrm{ab}}$ & $4.80 \pm 0.98^{\mathrm{abc}}$ & $0.3491 \pm 0.02^{\mathrm{a}}$ \\
N2-A1 & $11.25 \pm 0.46^{\mathrm{ab}}$ & $1.67 \pm 0.37^{\mathrm{b}}$ & $3.10 \pm 0.44^{\mathrm{bc}}$ & $0.3220 \pm 0.07^{\mathrm{ab}}$ \\
N2-A2 & $10.09 \pm 0.25^{\mathrm{b}}$ & $1.04 \pm 0.04^{\mathrm{b}}$ & $1.87 \pm 0.15^{\mathrm{c}}$ & $0.1980 \pm 0.02^{\mathrm{bc}}$ \\
$120 \mathrm{~N}-60 \mathrm{P}-30 \mathrm{~K}$ & $6.99 \pm 0.17^{\mathrm{c}}$ & $2.45 \pm 0.87^{\mathrm{ab}}$ & $5.87 \pm 1.01^{\mathrm{ab}}$ & $0.2978 \pm 0.06^{\mathrm{ab}}$ \\
\hline
\end{tabular}

Mean \pm standard deviation values followed of different letter in each row, are significantly different $(\mathrm{p}<0.05)$. 
Table 3. Texture parameters of tortilla

\begin{tabular}{|c|c|c|c|c|}
\hline Treatment & $\begin{array}{l}\text { Tensile strength } \\
\text { (N) }\end{array}$ & $\begin{array}{l}\text { Extensibility } \\
(\mathrm{mm})\end{array}$ & $\begin{array}{l}\text { Rollability } \\
\text { (N) }\end{array}$ & $\begin{array}{c}\text { Rollability } 24 \mathrm{~h} \\
\text { (N) }\end{array}$ \\
\hline N0-A0 & $4.34 \pm 0.48^{a b c}$ & $4.44 \pm 0.36^{\mathrm{a}}$ & $0.28 \pm 0.08^{c}$ & $0.60 \pm 0.01^{b}$ \\
\hline N0-A1 & $4.80 \pm 0.33^{\mathrm{a}}$ & $4.55 \pm 0.28^{\mathrm{a}}$ & $0.41 \pm 0.04^{b c}$ & $0.85 \pm 0.04^{\mathrm{ab}}$ \\
\hline $\mathrm{N} 0-\mathrm{A} 2$ & $3.31 \pm 0.52^{\mathrm{bcd}}$ & $4.83 \pm 0.98^{\mathrm{a}}$ & $0.37 \pm 0.02^{\mathrm{c}}$ & $1.00 \pm 0.11^{\mathrm{a}}$ \\
\hline N1-A0 & $3.08 \pm 0.52^{\mathrm{cd}}$ & $2.57 \pm 0.33^{\mathrm{cd}}$ & $0.62 \pm 0.04^{\mathrm{a}}$ & $1.04 \pm 0.02^{\mathrm{a}}$ \\
\hline N1-A1 & $4.04 \pm 0.07^{\mathrm{abc}}$ & $2.82 \pm 0.22^{\mathrm{bcd}}$ & $0.62 \pm 0.05^{\mathrm{a}}$ & $0.74 \pm 0.01^{\mathrm{ab}}$ \\
\hline N1-A2 & $3.56 \pm 0.57^{\mathrm{abcd}}$ & $2.33 \pm 0.33^{\mathrm{d}}$ & $0.53 \pm 0.09^{a b}$ & $0.84 \pm 0.03^{\mathrm{ab}}$ \\
\hline $\mathrm{N} 2-\mathrm{A} 0$ & $3.83 \pm 0.42^{\mathrm{abcd}}$ & $3.75 \pm 0.24^{\mathrm{abc}}$ & $0.55 \pm 0.03^{\mathrm{ab}}$ & $0.89 \pm 0.09^{\mathrm{ab}}$ \\
\hline $\mathrm{N} 2-\mathrm{A} 1$ & $4.56 \pm 0.79^{\mathrm{ab}}$ & $3.99 \pm 0.27^{\mathrm{ab}}$ & $0.56 \pm 0.02^{\mathrm{a}}$ & $0.87 \pm 0.09^{\mathrm{ab}}$ \\
\hline $\mathrm{N} 2-\mathrm{A} 2$ & $2.55 \pm 0.25^{\mathrm{d}}$ & $2.91 \pm 0.68^{\mathrm{bcd}}$ & $0.65 \pm 0.02^{\mathrm{a}}$ & $1.07 \pm 0.07^{\mathrm{a}}$ \\
\hline $120 \mathrm{~N}-60 \mathrm{P}-30 \mathrm{~K}$ & $4.34 \pm 0.64^{\mathrm{abc}}$ & $3.05 \pm 0.17^{\text {bcd }}$ & $0.62 \pm 0.05^{\mathrm{a}}$ & $0.86 \pm 0.11^{\mathrm{a}}$ \\
\hline
\end{tabular}

Mean \pm standard deviation values followed of different letter in each row, are significantly different $(p<0.05)$.

amount of ovine manure applied at $50 \mathrm{tha}^{-1}$. This resistance to stress represents a $41 \%$ lower value than the samples that did not have any treatment with nejayote or ovine manure (N0-A0). It is also revealed that there was an interaction between the addition of nejayote and ovine manure. The high concentrations of nejayote applied at $150 \mathrm{~m}^{3} \mathrm{ha}^{-1}$ and the low levels of ovine manure applied at $25 \mathrm{t} \mathrm{ha}^{-1}$ (N2-A1) had a positive influence on maize behaviour during nixtamalization. Concerning the tensile strength of the tortillas, they showed no statistically significant difference regarding those produced without nejayote or ovine manure during plant growth. The extensibility results for the masa obtained from maize without nejayote or manure during the development of plant and maize cobs were similar to those reported by Ruiz-Gutiérrez et al. (2012). Masa and tortillas prepared with maize treated with N2-A1 and N0-A1 showed a statistically significant difference in extensibility. However, N0-A0 and N0-A2 presented an increase in extensibility, although their resistance to stress was lower when compared to the samples with treatment.

The rollability test showed that, in freshly prepared tortillas, both the addition of nejayote and maize treated with chemical fertilization presented an increase in the force required to roll the tortillas. Compared to the samples without nejayote and ovine manure, the addition of ovine manure has a significant effect on the rollability loss. However, the results obtained coincide with those reported by Peña-Reyes et al. (2017), who evaluated the impact of different nixtamalization conditions on the textural properties and reporting values between 0.22 to $0.29 \mathrm{~N}$ in freshly prepared tortillas. In the present study, the addition of nejayote as a fertilizer during the development and growth of maize cob is the factor with the most considerable influence on rollability. Nonetheless, the results obtained were lower than $0.8 \mathrm{~N}$, which implies that they had an acceptable rollability behaviour compared to other studies (Peña-Reyes et al., 2017; Wu and Arntfield, 2016), in which the subjective rollability was greater than 4. Moreover, water absorption is an important parameter which depends on the characteristics of maize, and therefore, on the nutritional conditions of the plant during the development of the maize cob. However, the results obtained after $24 \mathrm{~h}$ of preparation showed that there was a statistically significant difference in the strength required to roll the tortillas in comparison with those without ovine manure, although they are still within the intervals reported in a study in which the capacity of subjective and objective rollability were evaluated.

\section{CONCLUSIONS}

1. Different fertilizer types produce changes in grain quality such as hectolitre weight, flotation index and hardness, and also resulted in physicochemical changes in flours and rheological and textural ones in masa and tortillas.

2. The protein content in flours obtained from maize grains treated with N2-A0 and N1-A1 were higher than those seen in flour resulting from treatment with a chemical fertilizer.

3. The inflection point obtained from the pasting profile of NI-A1 was the highest one out of all the flour slurries tested, it was obtained from fertilized maize grains with $75 \mathrm{~m}^{3} \mathrm{ha}^{-1}$ of nejayote and $25 \mathrm{tha}^{-1}$ of ovine manure. This fact shows that a period of water absorption of the starch granules before maximum viscosity is reached results in an improvement in the cohesiveness of the masa and the rollability of the tortilla.

4. The organic fertilizer N2-A2 had the highest content of nitrogen, and the masa obtained from the fertilized maize showed the lowest elastic and viscous moduli, but it produced the highest rollability in tortillas.

5. The texture profile analysis for masa and tortilla (tensile strength and rollability) showed that treatments with more ovine manure, considerably reduced the cohesiveness 
of the masa obtained with fertilized maize. Likewise, the treatments with nejayote as a fertilizer influenced the rollability of tortilla.

6. The highest concentrations of nejayote applied at $150 \mathrm{~m}^{3} \mathrm{ha}^{-1}$ and the low levels of ovine manure applied at $25 \mathrm{t} \mathrm{ha}^{-1}$ (N2-A1) had a positive influence on maize behaviour during nixtamalization and tortilla production. Therefore, the application of organic fertilizer (nejayote with ovine manure) during the growth of the maize plant is a positive alternative that could replace chemical fertilizers.

7. In this research, changes to the physicochemical properties of flours (chemical analysis, pasting profile, water solubility index and swelling power) as well as the textural and rheological properties in masa and tortilla were evaluated. Future studies could continue the work and determine if the application of biofertilizers (nejayote and ovine manure) during the growth period of the plant modifies the phenolic and ferulic compounds and hence the antioxidant capacity of maize grains and tortillas.

Conflict of interest: The Authors confirm that there is no conflict of interest affecting their work as researchers.

\section{ACKNOWLEDGMENTS}

The authors would like to thank the Faculty of Higher Studies Cuautitlan -UNAM and the staff of the research project PIAPI 1821 and 1657 for their support. In the same manner, the authors show gratitude to Dr. Gabriela Sánchez Hernández and Dr. Martha Yolanda Quezada Viay for their technical support and Rancho "La Laguna" at Ahuazotepec, Puebla, for the donation of maize grains. In the same way, we thank the Laboratorio de Fisicoquímica de Alimentos of CFATA-UNAM Juriquilla campus for the support in the use of equipment.

\section{REFERENCES}

AACC, 2000. Approved methods of the American Association of Cereal Chemists. Method 84-10 and 08-01. St. Paul, MN: American Association of Cereal Chemists. https://doi.org/10.1016/s0144-8617(01)00358-7

Abdalaa L.J., Vitantonio-Mazzinia L.N., Gerdea J.A., Martí R.F., Murtaghe G., and Borrás L., 2018. Dry milling grain quality changes in Argentinean maize genotypes released from 1965 to 2016. Field Crop. Res., 226, 74-82. https://doi.org/10.1016/j.fcr.2018.07.008

Acosta-Estrada B.A., Villela-Castrejón J., Perez-Carrillo E., Gómez-Sánchez C.E., and Gutiérrez-Uribe J.A., 2019. Effects of solid-state fungi fermentation on phenolic content, antioxidant properties and fiber composition of lime cooked maize by-product (nejayote). J. Cereal Sci., 90, 102837. https://doi.org/10.1016/j.jcs.2019.102837

Altenbach S.B., DuPont F.M., Kothari K.M., Chan R., Johnson E.L., and Lieu D., 2003. Temperature, water and fertilizer influence the timing of key events during grain development in a US spring wheat. J. Cereal Sci., 37, 9-20. https://doi.org/10.1006/jcrs.2002.0483
Amador-Rodriguez K.Y., Silos-Espino H., Valera-Montero L.L., Perales-Segovia C., Flores-Benitez S., and MartinezBustos F., 2019. Physico-chemical, thermal, and rheological properties of nixtamalized creole corn flour produced by high-energy milling. Food Chem., 283, 481-488. https://doi.org/10.1016/j.foodchem.2019.01.044

Athene M.D., 2001. Scattering studies of the internal structure of starch granules. Starch/Stärke 53, 504-512. https://doi.org/10.1002/1521-379x(200110)53:10<504:: aid-star504>3.0.co;2-5

Ayala-Rodríguez A.E., Gutiérrez-Dorado R., Milán-Carrillo J., Mora-Rochín S., López-Valenzuela J., Valdez-Ortiz A., Paredes-López O., and Reyes-Moreno C., 2009. Nixtamalised flour and tortillas from transgenic maize (Zea mays L.) expressing amarantin: Technological and nutritional properties. Food Chem., 214, 50-56.

https://doi.org/10.1016/j.foodchem.2008.09.017

Bello-Perez L.A., Flores-Silva P.C., Agama-Acevedo E., Figueroa-Cardenas J.D., Lopez-Valenzuela J.A., and Campanellla O.H., 2014. Effect of the nixtamalization with calcium carbonate on the indigestible carbohydrate content and starch digestibility of corn tortilla. J. Cereal Sci., 60, 421-425.

Camelo-Méndez G., Agama-Acevedo E., Tovar J., and BelloPérez, L.A., 2017. Functional study of raw and cooked blue maize flour: Starch digestibility, total phenolic content and antioxidant activity. J. Cereal Sci., 76, 179-185.

https://doi.org/10.1016/j.jcs.2017.06.009

Contreras-Jiménez B., Gaytán-Martínez M., Morales-Sánchez E., Figueroa-Cardenas J.D., Pless R., González-Jasso E., Méndez-Montalvo G., and Velázquez G., 2017. Effects of tempering time, $\mathrm{Ca}(\mathrm{OH})_{2}$ concentration, and particle size on the rheological properties of extruded corn flour. Cereal Chem., 94, 230-236. https://doi.org/10.1094/cchem-03-16-0058-r

Chel-Guerrero L., Parra-Pérez J., Betancur-Ancona D., Castellanos-Ruelas A., and Solorza-Feria J., 2014. Chemical, rheological and mechanical evaluation of maize dough and tortillas in blends with cassava and malanga flour. J. Food Sci. Tech., 52, 4387-4395. https://doi.org/10.1007/s13197-014-1504-6

Daglia M., 2012. Polyphenols as antimicrobial agents. Curr. Opin. Biotech., 23, 174-181.

Domínguez-Hernández M.E., Zepeda-Bautista R., DomínguezHernández E., Valderrama-Bravo M.C., HernándezSimón L.M., 2020. Effect of lime water-manure organic fertilizers on the productivity, energy efficiency and profitability of rainfed maize production. Arch. Agron. Soil Sci., 66, 3, 370-385. https://doi.org/10.1080/03650340.2019.1616287.

Flores-Farías R., Martínez-Bustos F., Salinas-Moreno Y., Chang Y.K., Hernández J.G., and Ríos E., 2000. Physicochemical and rheological characteristics of commercial nixtamalised Mexican maize flours for tortillas. J. Sci. Food Agric., 80, 657-664.https://doi.org/10.1002/(sici)109700102000050180:6<657::aid-jsfa576>3.0.co;2-j

Gaytán-Martínez M., Figueroa J.D.C., Morales-Sánchez E., Vázquez-Landaverde P.A., and Martínez-Flores H.E., 2011. Physicochemical properties of masa and corn tortilla made by ohmic heating. African J. Biotech., 10, 16028-16036. https://doi.org/10.5897/ajb11.1820 
Jan K.N., Panesar P.S., Rana J.C., and Singh S., 2017. Structural, thermal and rheological properties of starches isolated from Indian quinoa varieties. Int. J. Biol. Macrom., 102, 315-322. https://doi.org/10.1016/j.ijbiomac.2017.04.027

Keeling P.L. and Myers A.M., 2010. Biochemistry and genetics of starch synthesis. Annu. Rev. Food. Sci. Technol., 1, 271303. https://doi.org/10.1146/annurev.food.102308.124214

Kethireddipalli P., Hung Y.C., McWatters K.H., and Phillips R.D., 2002. Effect of milling method (wet compared with dry) on the functional properties of cowpea (Vigna unguiculata) pastes and end product (akara) quality. J. Food Sci., 67, 48-52. https://doi.org/10.1111/j.1365-2621.2002.tb11357.x

López-Pacheco I.Y., Carrillo-Nieves D., Salinas-Salazar C., Silva-Núñez A., Arévalo-Gallegos A., Barceló D., Afewerki S., Hafiz M.N.I., Parra-Saldívar R., 2019. Combination of nejayote and swine wastewater as a medium for Arthrospira maxima and Chlorella vulgaris production and wastewater treatment. Sci. Total Environ., 676, 356-367.

https://doi.org/10.1016/j.scitotenv.2019.04.278

Mahmood F., Khan I., Ashraf U., Shahzad T., Hussain S., Shahid M., Abid M., and Ullah S., 2017. Effects of organic and inorganic manures on maize and their residual impact on soil physico-chemical properties. J. Soil Sci. Plant Nut., 17(1), 22-32.

https://doi.org/10.4067/s0718-95162017005000002

Martınez-Flores H.E., Garnica-Romo M.G., Romero V.J.U., and Yahuaca J.B., 2006. Evaluating the quality of lipids during alkaline cooking of corn. J. Food Lipids, 13, 177-185. https://doi.org/10.1111/j.1745-4522.2006.00043.x

Mir S.A., Bosco S.J.D., and Sunooj K.V., 2013. Evaluation of physical properties of rice cultivars grown in the temperate region of India. Retrieved from Int. Food Res. J., 20, 1521-1527.

Niño-Medina G., Carvajal-Millán E., Lizardi J., Rascon-Chu A., Márquez-Escalante J., Gardea A., et al., 2009. Maize processing waste water arabinoxylans: Gelling capability and cross-linking content. Food Chem., 115, 1286-1290. https://doi.org/10.1016/j.foodchem.2009.01.046

Osorio-Díaz P., Agama-Acevedo E., Bello-Pérez L.A., IslasHernández J.J., Gómez-Montiel N.O., and Paredes- López O., 2011. Effect of endosperm type on texture and in vitro starch digestibility of maize tortillas. LWT- Food Sci. Tech., 44, 611-615. https://doi.org/10.1016/j.lwt.2010.09.011

Pei-Yin L. and Hsi-Mei L., 2011. Bioactive compounds in rice during grain development. Food Chem., 127, 86-93.

Peña-Reyes R.A., Ramírez-Romero G.A., Fernández-Perrino F.J., and Cruz-Guerrero A.E., 2017. Effect of nixtamalization processing temperature on maize hydration and the textural properties of masa and tortillas. J. Food Process. Pres., 41, e13136. https://doi.org/10.1111/jfpp.13136

Pérez J., Muñoz-Dorado J., De la Rubia T., and Martínez J., 2002. Biodegradation and biological treatments of cellulose, hemicellulose and lignin: an overview. Int. Microbiol., 5, 53-63. https://doi.org/10.1007/s10123-002-0062-3

Ramírez-Jiménez K., Rangel-Hernández J., Morales-Sánchez E., Loarca-Piña G., and Gaytán-Martínez M., 2019. Changes on the phytochemicals profile of instant corn flours obtained by traditional nixtamalization and ohmic heating process. Food Chem., 276, 56-62.

https://doi.org/10.1016/j.foodchem.2018.09.166
Rincón-Londoño N., Vega-Rojas N., Contreras-Padilla M., AcostaOsorio A., and Rodríguez-García M.E., 2016. Analysis of the pasting profile in corn starch: structural, morphological, and thermal transformations. Int. J. Biol. Macrom., 91, 106-114. https://doi.org/10.1016/j.ijbiomac.2016.05.070

Rocha-Villarreal V., Hoffmann J.F., Levien V.N., SernaSaldivar S.O., and García-Lara S., 2018. Hydrothermal treatment of maize: Changes in physical, chemical, and functional properties. Food Chem., 263, 225-231. https://doi.org/10.1016/j.foodchem.2018.05.003

Ruiz-Gutiérrez M.G., Quintero-Ramos A., Meléndez-Pizarro C.O., Talamás-Abbud R., Barnard J., Márquez-Meléndez R., and Lardizábal-Gutiérrez D., 2012. Nixtamalization in two steps with different calcium salts and the relationship with chemical, texture and thermal properties in masa and tortilla. J. Food Process Eng., 35, 772-783. https://doi.org/10.1111/j.1745-4530.2010.00627.x

SAGARPA, Secretariat of Agriculture, Fisheries and Food, 2002. Mexican Standard NMXFF- 034/1-SCFI-2002. Non industrialized food products for human consumption. Cereals white corn for alkaline process of corn tortillas and nixtamalized corn products. Specifications and test method. General Direction of Standards, SAGARPA (in Spanish). SAGARPA, Mexico. https://doi.org/10.4067/s071807642006000600020

Salazar-Sosa E., Trejo-Escareño H.I., Vázquez-Vázquez C., López-Matínez J.D., Fortis-Hernández M., ZuñigaTarango R., and Amado-Álvarez J.P., 2009. Distribution of available nitrogen in the soil profile after appliying bovine manure in corn forage (in Spanish). Terra Latinoam., 27, 373-382. https://doi.org/10.29312/remexca.v4i5.1171

Santiago-Ramos D., Figueroa-Cárdenas J.D., Véles-Medina J.J., and Mariscal-Moreno R.M., 2017. Changes in the thermal and structural properties of maize starch during nixtamalization and tortilla-making processes as affected by grain hardness. J. Cereal Sci., 74, 72-78.

https://doi.org/10.1016/j.jcs.2017.01.018

Santiago-Ramos S., Figueroa-Cárdenas J.D., Véles-Medina J.J., Mariscal-Moreno R.M., Reynoso-Camacho R., Ramos-Gómez M., Gaytán-Martínez M., and MoralesSánchez E., 2015. Resistant starch formation in tortillas from in ecological nixtamalization process. Cereal Chem., 92, 185-192. https://doi.org/10.1094/cchem-08-14-0170-r

Schröder J.J., Vermeulen G.D., Van Der Schoot J.R., Van Dijk W., Huijsmans J.F.M., Meuffels G.J.H.M., and Van Der Schans D.A., 2015. Maize yields benefit from injected manure positioned in bands. Euro. J. Agron., 64, 29-36. https://doi.org/10.1016/j.eja.2014.12.011

Seebauer J.R., Singletary G.W., Krumpelman P.M., Ruffo M.L., and Below F., 2010. Relationship of source and sink in determining kernel composition of maize. J. Exp. Bot., 61, 511-519. https://doi.org/10.1093/jxb/erp324

Shi L., Li W., Sun J., Qiu Y., Wei X., Luan G., Hu Y., and Tatsumi E., 2016. Grinding of maize: The effects of fine grinding on compositional, functional and physicochemical properties of maize flour. J. Cereal Sci., 68, 25-30. https://doi.org/10.1016/j.jcs.2015.11.004

Song Z., Wang J., Sun M., Wu J., Gong Ch., and Liu G., 2016. Effects of organic fertilizer applications on starch changes in tobacco (Nicotiana tabacum L.) leaves during maturation. Soil Sci. Plant Nutr., 62, 173-179. https://doi.org/10.1080/00380768.2016.1162110 
Suarez-Meraz A., Ponce-Vargas S.M., Lopez-Maldonado J.T., Cornejo-Bravo J.M., Oropeza-Guzman M.T., LopezMaldonado E.A., 2016. Eco-friendly innovation for nejayote coagulation-flocculation process using chitosan: Evaluation through zeta potential measurements. Chem. Eng. J., 284, 536-542. https://doi.org/10.1016/j.cej.2015.09.026

Thachil M.T., Chouksey M.K., and Gudipati V., 2014. Amyloselipid complex formation during extrusion cooking: effect of added lipid type and amylose level on corn-based puffed snacks. Food Sci. Technol., 49, 309-314. https://doi.org/10.1111/ijfs.12333

Thitisaksakul M., Jiménez R.C., Arias M.C., and Beckles D.M., 2012. Effects of environmental factors on cereal starch biosynthesis and composition. J. Cereal Sci., 56, 67-80. https://doi.org/10.1016/j.jcs.2012.04.002

Tofiño A., Mauricio R.H., and Ceballos H., 2007. Effect of abiotic stress on the synthesis and degradation of starch. A review (in Spanish). Agronomía Colombiana, 25, 245-254.

USDA, 2010. Composting. In: National Engineering Handbook. United States: USDA NRCS. https://directives.sc.egov.usda.gov/viewerFS.aspx?id=3850

Valderrama-Bravo C., Domínguez-Pacheco A., HernándezAguilar C., Zepeda-Bautista R., Del Real-López A., Pahua-Ramos M.E., Arellano-Vázquez J.L., and MorenoMartínez E., 2017. Physical and chemical characterization of masa and tortillas from parental lines, single crosses and one hybrid of maize. Int. Agrophys., 31, 129.138. https://doi.org/10.1515/intag-2016-0030

Valderrama-Bravo C., Gutiérrez-Cortez E., Contreras-Padilla M., Oaxaca-Luna A., Del Real López A., EspinosaArbelaez D.G., and Rodríguez-García M.E., 2013. Physic-mechanic treatment of nixtamalization by-product (nejayote). CyTA-J. Food, 11, 75-83. https://doi.org/10.1080/19476337.2013.781680

Valderrama-Bravo C., Gutiérrez-Cortez E., Contreras-Padilla M., RojasMolina I., Mosquera J.C., Rojas-Molina A., Beristain F., and Rodríguez-García M.E., 2012. Constant pressure filtration of lime water (nejayote) used to cook kernels in maize processing. J. Food Eng., 110, 478-486. https://doi.org/10.1016/j.jfoodeng.2011.12.018

Valderrama-Bravo C., López-Ramírez Y., Jiménez-Ambriz S., Oaxaca-Luna A., Domínguez-Pacheco A., HernándezAguilar C., and Moreno-Martínez E., 2015. Changes in chemical, viscoelastic, and textural properties of nixtamalized dough with nejayote. LWT-Food Sci. Tech., 61, 496502. https://doi.org/10.1016/j.lwt.2014.12.038

Vázquez-Carrillo M.G., Ramos D.S., Salinas-Moreno Y., RojasMartínez I., Arellano-Vázquez J., Velázquez-Cardelas G.A., and Espinosa-Calderón A., 2012. Genotype-environment interaction of yield and grain and tortilla quality of maize hybrids at the highlands of Tlaxcala, Mexico (in Spanish). Rev. Fitotec. Mex., 35, 229-237.

https://doi.org/10.29312/remexca.v9i7.1357

Vázquez-Carrillo M.G., Santiago-Ramos D., Gaytán-Martínez M., Morales-Sánchez E., and Guerrero-Herrera M.J., 2015. High oil content maize: Physical, thermal and rheological properties of grain, masa, and tortillas. LWT - Food Sci. Tech., 60, 156-161.https://doi.org/10.1016/j.lwt.2014.07.043

Vilche C., Gely M.C., and Santalla, E., 2003. Physical properties of quinoa seeds. Biosyst. Eng., 86, 59-65. https:/doi.org/10.1016/s1537-5110(03)00114-4

Villada J.A., Sánchez-Sinencio F., Zelaya-Angel O., GutiérrezCortez E., and Rodríguez-García M.E., 2017. Study of the morphological, structural, thermal, and pasting corn transformation during the traditional nixtamalization process: From corn to tortilla. J. Food Eng., 212, 242-251. https://doi.org/10.1016/j.jfoodeng.2017.05.034

Vitaglione P., Napolitano A., and Fogliano V., 2008. Cereal dietary fiber: a natural functional ingredient to deliver phenolic compounds into the gut. Trends Food Sci. Tech., 19, 451-463. https://doi.org/10.1016/j.tifs.2008.02.005

Wajira S.R. and David S.J., 2006. Gelatinization and solubility of corn starch during heating in excess water: New Insights. J. Agr. Food Chem., 54, 3712-3716. https://doi.org/10.1021/jf0529114

Wang L., Xie B.J., Shi J., Xue S., Deng Q.C., Wei Y., and Tian B.Q., 2010. Physicochemical properties and structure of starches from Chinese rice cultivars. Food Hydrocoll., 24, 208-216. https://doi.org/10.1016/j.foodhyd.2009.09.007

Wu M. and Arntfield S., 2016. Influence of added soy presscake and soy flour on some physical and sensory properties of corn tortillas. J. Food Sci., 81. S2552-S2558. https://doi.org/10.1111/1750-3841.13433

Zepeda-Bautista R., Carballo-Carballo A., Muñoz-Orozco A., Mejía-Contreras J.A., Figueroa-Sandoval B., and GonzálezCossio F.V., 2007. Nitrogen fertilization effect on the physical, structural and alkaline-cooking quality characteristics of grain from corn hybrids (in Spanish). Agric. Tec. Mex., 33, 17-24.

Zhang Y.G., Yang S., Ming M.F., Ping C.J., Zhang Y., Wang R., Xu Z.W., Bai Y.F., and Jiang Y., 2015. Sheep manure application increases soil exchangeable base cations in a semiarid steppe of Inner Mongolia. J. Arid Land, 7, 361-369. https://doi.org/10.1007/s40333-015-0004-5 